\title{
OSCILLATORY JOINT MOBILIZATION AS A PHYSIOTHERAPEUTIC TREATMENT OF TEMPOROMANDIBULAR DYSFUNCTION: A CASE REPORT
}

\section{MOBILIZAÇÃO ARTICULAR OSCILATÓRIA COMO TRATAMENTO FISIOTERÁPICO DA DISFUNÇAOO TEMPOROMANDIBULAR: UM RELATO DE CASO}

\author{
Maria do Socorro Medeiros da SILVA ${ }^{1}$ \\ smedeiros92@hotmail.com \\ Júlio Leite de ARAÚJO-JÚNIOR² \\ juniorleitearaujo@hotmail.com \\ Nathalia Matos de SANTANA ${ }^{3}$ \\ nathaliam15@hotmail.com \\ Rômulo Bezerra de OLIVEIRA ${ }^{4}$ \\ romulobezerraoliveira@hotmail.com \\ Vitor Engrácia VALENTI ${ }^{5}$ \\ vitor.valati@gmail.com \\ Eduardo DIAS-RIBEIRO ${ }^{6}$ \\ eduardo_ufpb@hotmail.com \\ Marco Antônio Farias de PAIVA ${ }^{7}$ \\ marcosafp2@hotmail.com \\ Andrey Alves PORTO ${ }^{8}$ \\ andrey.alpo@hotmail.com
}

\footnotetext{
Fisioterapeuta pelo Centro Universitário Dr. Leão Sampaio (UNILEÃO), Juazeiro do Norte, CE, Brasil.

Residente em Cirurgia e Traumatologia Buco-Maxilo-Facial, Universidade Federal da Paraíba (UFPB), João Pessoa, PB, Brasil.

Mestranda em Ciências da Saúde pela Faculdade de Medicina do ABC Paulista, Santo André, SP, Brasil.

Professor do Programa de Pós-Graduação em Fisioterapia, UNESP, Presidente Prudente, SP, Brasil.

Professor do Programa de Pós-Graduação em Fisioterapia, UNESP, Presidente Prudente, SP, Brasil.

Professor do Programa de Residência em Cirurgia e Traumatologia Buco-Maxilo-Facial da UFPB, João Pessoa, PB, Brasil.

Coordenador do Serviço de Cirurgia e Traumatologia Buco-Maxilo-Facial da UFPB, João Pessoa, PB, Brasil.

Professor do Programa de Pós-Graduação em Fisioterapia, UNESP, Presidente Prudente, SP, Brasil.
} 


\section{ABSTRACT}

Introduction: The temporomandibular joint (TMJ) acts during chew, swallowing, yawning, conversation and in activities involving jaw movements. Temporomandibular Dysfunction (TMD) is a set of disorders involving the masticatory muscles in the TMJ and associated structures. Joint mobilization aims to relief pain and restoring the function of the compromised body segment, increasing its degree of mobility. Objective: We aimed to evaluate the influence of oscillatory joint mobilization on TMD. Method: A descriptive case study with a patient who presented a clinical diagnosis of TMD in the Clinical School of Physiotherapy of the Leão Sampaio School, Juazeiro do Norte, CE, Brazil, from September 3 to October 6 of 2014, twice a week, lasting 40 minutes, a total of 10 visits. Results: The patient presented a gain in the range of motion of the mouth opening (from $17 \mathrm{~mm}$ to $46 \mathrm{~mm}$ ), pain relief (from grade 6 to grade 0 on the Visual Analogue Scale) and improvement in muscle function. Conclusion: Oscillatory joint mobilization in TMD may be effective in increasing mandibular range of motion and opening of the mouth, as well as in reducing TMJ pain and masticatory musculature.

DESCRIPTORS: PAIN; TEMPOROMANDIBULAR JOINT DYSFUNCTION SYNDROME; PHYSIOTHERAPY.

\section{RESUMO}

Introdução: A articulação temporomandibular (ATM) atua durante a mordida, a deglutição, o bocejo, a conversação e as atividades envolvendo movimentos do maxilar. Disfunção temporomandibular (DTM) é um conjunto de distúrbios envolvendo os músculos mastigatórios na ATM e estruturas associadas. A mobilização conjunta visa a dor de alívio e a restauração da função do segmento comprometido do corpo, aumentando seu grau de mobilidade. Objetivo: Pretendemos avaliar a influência da mobilização articular oscilatória na DTM. Método: Trata-se de um estudo de caso com paciente que compareceu para diagnóstico de DTM na Clínica Escola de Fisioterapia da UNILEÃO, Juazeiro do Norte, CE, Brasil, de 3 de setembro a 6 de outubro de 2014, duas vezes por semana, com duração de 40 minutos, totalizando 10 visitas. Resultados: O paciente apresentou um ganho no intervalo de movimento da abertura da boca (de $17 \mathrm{~mm}$ a $46 \mathrm{~mm}$ ), alívio da dor (do grau 6 ao grau 0 na Escala Visual Analógica) e melhora na função muscular. Conclusão: A mobilização das articulações oscilatórias na DTM pode ser eficaz no aumento da amplitude de movimento mandibular e na abertura da boca, bem como na redução da dor da ATM e musculatura mastigatória.

DESCRITORES: DOR; SÍNDROME DA DISFUNÇÃO DA ARTICULAÇÃO TEMPOROMANDIBULAR; FISIOTERAPIA.

\section{INTRODUCTION}

The human temporomandibular joint is a specialized structure, with a particular anatomical disposition classified as complex gynglimo-arthrodial, which allows to perform rotational and translational movements simultaneously, giving it a wide and varied functional capacity ${ }^{1,2}$.

Mandibular biomechanics considers that range of motion is functional for most activities of the mandible if there is $40 \mathrm{~mm}$ of interincisive aperture ${ }^{3}$. This movement should comprise approximately $25 \mathrm{~mm}$ of rotation and $15 \mathrm{~mm}$ of translation. Temporomandibular ligaments are responsible for limiting joint mobility in all directions. The normal resting position of the jaw is with the lips closed and the teeth separated by a few millimeters. Therefore, functional or structural imbalances in the masticatory system may give rise to a TMJ dysfunction².

Manual techniques are applied in the physiotherapeutic treatment and are defined as examination 
and treatment by the hands ${ }^{3}$. Among its methods we include articulation manipulation and mobilization.

The oscillatory joint mobilization refers to the passive accessory movements that aim at the recovery of the arthrokinematics, which is the movements of rotation, rolling and sliding between the articular surfaces. Its reestablishment promotes joint congruence, reduces mechanical friction in the joint, improves pain, edema and, consequently, the function of the compromised body segment, increasing its degree of mobility'.

Being aware of the high prevalence of temporomandibular disorders and its symptomatology that impairs health quality of people around the world, we aimed to evaluate the influence of oscillatory joint mobilization on the temporomandibular dysfunction of a patient.

\section{CASE REPORT}

A 40-years-old, female, business occupation, eight-hour-workday. The patient presented a clinical diagnosis of TMD in the Clinical School of Physiotherapy of the Leão Sampaio School, Juazeiro do Norte, CE, Brazil.

In the anamnesis, the patient reported a history of muscular pains and tensions in the neck, shoulders and back regions for more than two years. One year ago she complains of dental wear, which is why she had to seek dental treatment for restorations.

Orthodontic appliance was prescribed to realign dental arches, but patient reports that she did not remain with the appliance because she felt uncomfortable. Four months ago, she sought the orthodontic service due to the rupture of dental restorations, during which time she was diagnosed with TMD with associated bruxism as the cause of tooth wear. The nocturnal myorelaxative plaque was prescribed, but the patient refused to use it because she felt uncomfortable. She was referred to the Physical Therapy service, where she underwent treatment using the Manual Therapy techniques: passive accessory oscillatory joint mobilization of the left TMJ, which was deployed in two, which were: "lower passive accessory oscillatory mobilization of the left condyle" and "Anterior passive accessory oscillatory mobilization of the left condyle" and passive oscillatory physiological mobilization. For the application, the patient was placed in dorsal decubitus, comfortably and in relaxation. The therapist did not exert force on the joint to be treated, her hand was positioned over the mandible (movable bone).

For the lower passive accessory oscillatory mobilization technique of the left condyle (Figure 1) the patient was instructed to actively perform the maximum buccal opening. 
SILVA MSM, ARAÚJO-JÚNIOR JL, SANTANA NM, OLIVEIRA RB, VALENTI VE, DIAS-RIBEIRO E, PAIVA MAF, PORTO AA. Oscillatory joint mobilization as a physiotherapeutic treatment of temporomandibular dysfunction: a case report. Rev. Odontol. Univ. Cid. São Paulo 2019 jan-mar; 31(1): 88-94

ISSN 1983-5183

Figure 1. Passive accessory oscillatory mobilization technique of the left TMJ.

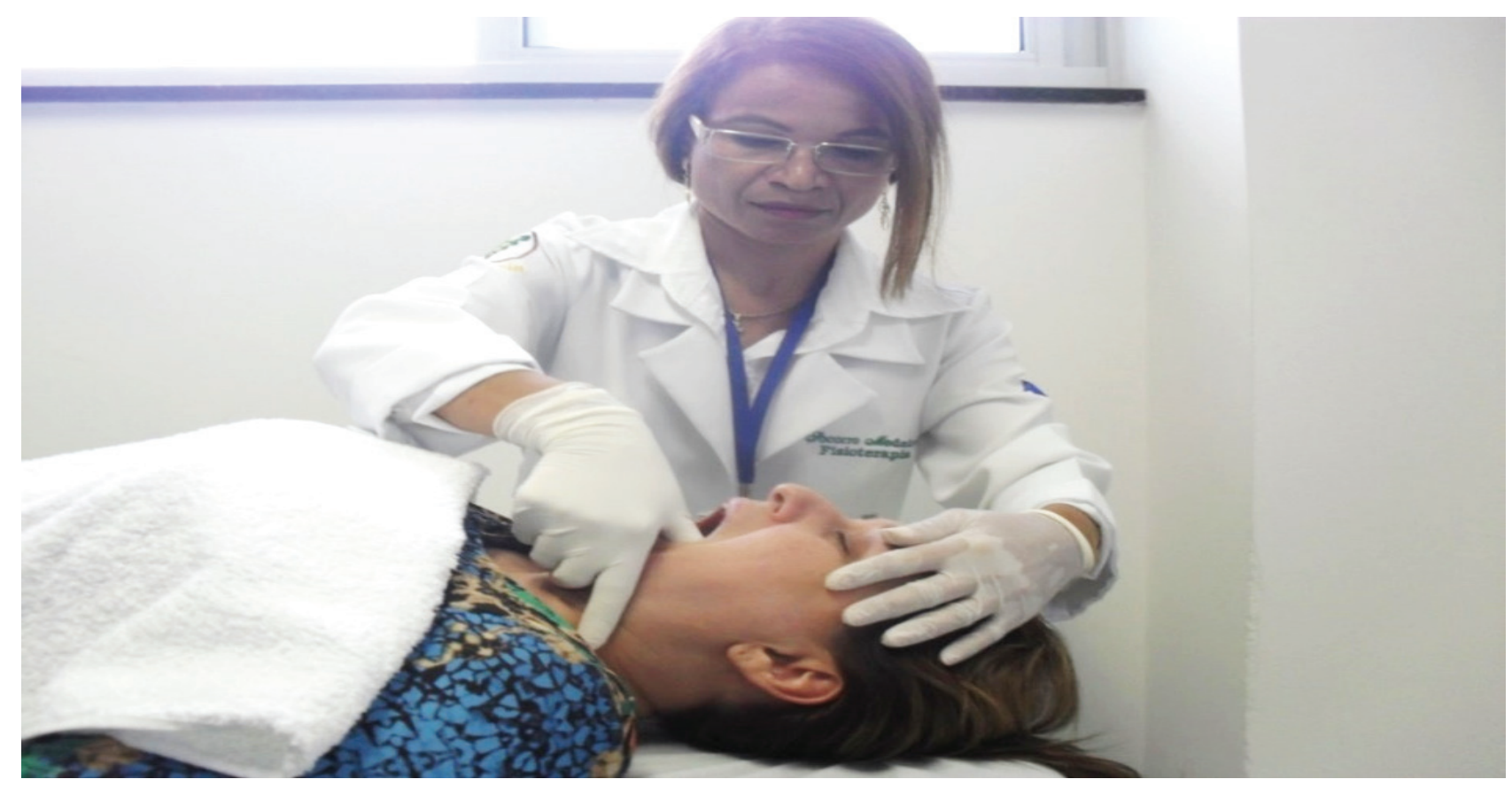

The therapist stands in position, close to the patient's head, facing the temporomandibular joint. The stabilizing cephalic hand supports the head ventrally or laterally on the same side of the joint being mobilized. The thumb of the caudal hand is mobilized in the lower molars and the other fingers wrapping the lower jaw laterally on the side to be mobilized. The stabilizing hand holds the head in position. The hand that mobilizes employs a firm force $(100 \mathrm{~g})$, applied in the caudal direction in the last two molars, making inferior slip in degree IV, movement of small amplitude at the end of the arc of movement.

Three series of lower accessory oscillatory movements of the left condyle were applied, each series of two to three oscillations per second, maintaining the rhythm and frequency for two minutes, with a rest interval of one minute between each series.

For the anterior passive accessory oscillatory mobilization technique of the left condyle, the procedure is similar to the previous technique, it differs only the direction of the slip that is anterior, maintaining all parameters of the technique previously mentioned, such as patient position, number of series, quantity of oscillations, duration and the same rest period.

In the technique of passive oscillatory physiological mobilization, maximum mouth opening was requested. The therapist positions herself close to the patient's head, facing the temporomandibular joint. The middle and index fingers of the caudal hand were placed on the lower incisors and the thumb on the jaw surrounding the jaw, the cephalic hand stabilizing the head. The hand that mobilizes, performs passive oscillatory physiological movements, in IV degree, end of the buccal opening arch. Three oscillations per second were performed for this technique, applied for two minutes and repeated for three sets, with a rest interval of one minute between each series. All the treatment was performed from September 3 to October 6 of 2014, twice a week, lasting 40 minutes, a total of 10 visits. 


\section{RESULTS AND DISCUSSION}

During the present study the patient underwent three evaluations. The first occurred before the first service, the second immediately after the fifth service and the third after the tenth service, according to the TMD evaluation form.

Regarding age and gender of the patient, it corroborates with other studies that claim to be the most prevalent and most severe TMD among females between 25 and 45 years old ${ }^{4}$. It also agrees that estrogen increases the excitability of primary afferent neurons and that low serum levels of estradiol increase the nociception of TMD symptom.

Regarding the type of occupation of the patient, it was found that the professional activity has been a source of muscular and emotional tension, which corroborates with studies that highlight the importance of the professional, physiotherapist, to relate the degree of occupational tension of the patient To the DTM presented by $i^{4}$. Increased tension can cause muscle hypertonicity and alter the functionality of the masticatory system.

Table 1 shows the findings regarding signs and symptoms of TMD of the patient under study, before, during and after treatment with oscillatory joint mobilization.

With respect to this result obtained, only one joint is referenced which normally becomes locked while the other joint is functioning normally 5 . Sometimes the jaw can really catch. TMJ dysfunction is always directly related to mandibular movement and may present as blocking sensations when the patient opens the mouth ${ }^{3,5}$.

Table 1. Evolution of the signs and symptoms of the patient under study,

\begin{tabular}{|c|c|c|c|}
\hline Signals and symptons & 1a Evaluation & $2^{\mathrm{a}}$ Evaluation & 3a Evaluation \\
\hline 1 - Estalido & Present & Absent & Absent \\
\hline $\begin{array}{l}2 \text { - Left condyle with hypomobility and left } \\
\text { mandibular deflection }\end{array}$ & Present & Present & Absent \\
\hline 3 - Bruxismo & Present & Present & Absent \\
\hline 4 - Chew only on the left side & Present & Present & Some times \\
\hline $\begin{array}{l}5 \text { - Retraction and muscle pain on the left side: } \\
\text { COM, masseter, trapezius }\end{array}$ & Present & Absent & Absent \\
\hline 6 - Hearing loss (sensation) & Present & Present & Absent \\
\hline Other: Posture & $\begin{array}{l}\text { Head anteroprojected, pro- } \\
\text { truding shoulders, thoracic } \\
\text { rectification. }\end{array}$ & & \\
\hline
\end{tabular}

Therefore, when the patient opened the mouth broadly, the midline of the mandible was deflected to the affected side (left side). The patient was also able to do normal lateral movement to the affected side (the condyle on the affected side only rotates) without pain. However, when movement was made to the unaffected side (right side) a movement restriction occurred because the condyle on the affected side could not translate beyond the previously functionally displaced disc. Event that occurred without the presence of pain, which corroborates with findings confirming that pain does not necessarily accompany this condition ${ }^{6}$. However, the resolution of hypomobility after application of oscillatory joint mobilization can be observed in evaluation ${ }^{3}$. 
SILVA MSM, ARAÚJO-JÚNIOR JL, SANTANA NM, OLIVEIRA RB, VALENTI VE, DIAS-RIBEIRO E, PAIVA MAF, PORTO AA. Oscillatory joint mobilization as a physiotherapeutic treatment of temporomandibular dysfunction: a case report. Rev. Odontol. Univ. Cid. São Paulo 2019 jan-mar; 31(1): 88-94

\section{ISSN 1983-5183}

As observed in item 6 of Table 1, which refers to the otologic symptom, the smothering sensation, referred in the first and second evaluation by the patient and absent after treatment, some studies have shown that TMD therapy can reduce ontological symptoms ${ }^{7,8,9}$.

In general, the evolution of the signs and symptoms listed in Table 1 was positive. Oscillatory joint mobilization in the treatment of TMD allows the improvement of both the biomechanical factors and the physiological, functional and emotional factors, thus reflecting the improvement of the patient's quality of life.

At physical examination, this pain was related to palpation and not to movement. After the treatment with oscillatory joint mobilization, in the second and third evaluation the pain was absent, confirming the findings in studies on the manipulation and mobilization, stating that abnormal overloads in periarticular structures can trigger pain ${ }^{10}$.

Figures $2 \mathrm{a}, \mathrm{b}$ and $\mathrm{c}$ demonstrate that the mouth opening ROM of the patient in the first evaluation was $17 \mathrm{~mm}$, after five visits with oscillatory joint mobilization, the opening reached $25 \mathrm{~mm}$, after the tenth service, last evaluation, the opening arrived at $46 \mathrm{~mm}$. In the physiotherapeutic treatment performed in this research, the oscillatory joint mobilization promoted a significant increase of joint movement, between the first and third evaluation.

Figure 2. Evolution of the range of motion for mandibular lowering during the study.
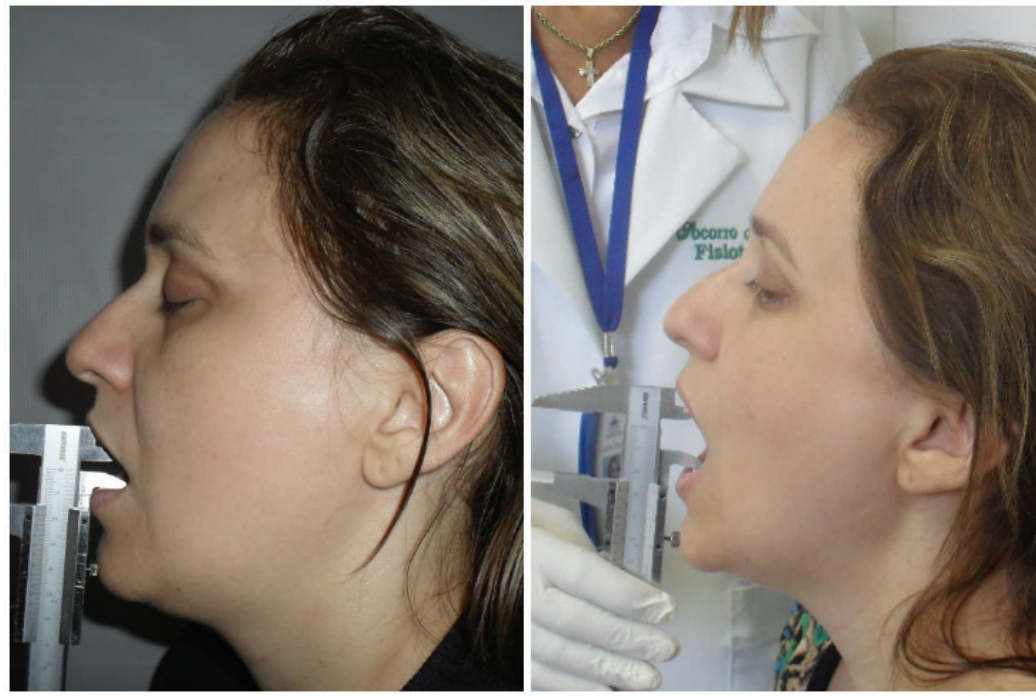

$B-25$ mm

\section{$A-17 \mathrm{~mm}$}

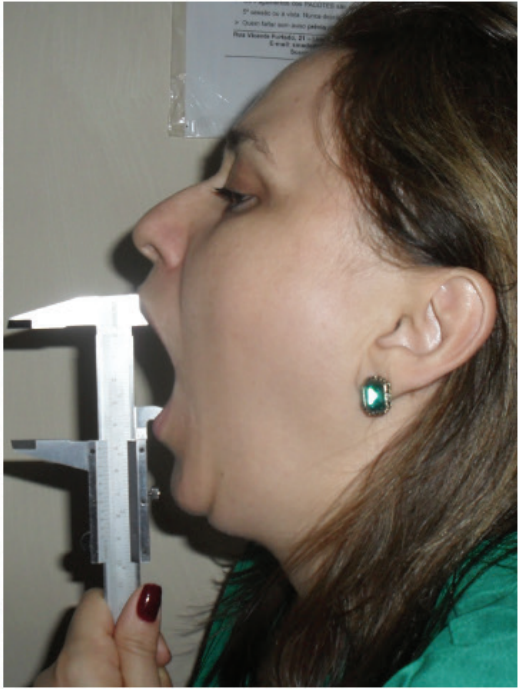

C- $46 \mathrm{~mm}$

It is important to record the high degree of satisfaction of the patient throughout the care and at the end of the care. In this sense, the psychological benefits of touch treatment should not be underestimated ${ }^{10}$.

\section{CONCLUSION}

The physiotherapeutic treatment based on oscillatory joint mobilization may be beneficial and of great importance in the treatment of TMD in dental patients. For, both biomechanical, physiological, functional and emotional factors were improved, thus reflecting the improvement in the quality of life of the patient with TMD. 


\section{REFERENCES}

1. CALIXTRE LB, Moreira RF, Franchini GH, Alburquerque-Sendin F, Oliveira AB. Manual therapy for the management of pain and limited range of motion in subjects with signs and symptoms of temporomandibular disorder: a systematic review of randomised controlled trials. Journal of oral rehabilitation 2015 Nov;42(11):847-61.

2. SILVA GR, Martins PR, Gomes KA, Mambro TRD, Abreu NS. O efeito de técnicas de terapias manuais nas disfunções craniomandibulares. Rev Bras Cien Med Saúde 2011 1(1):1722.

3. OLIVEIRA AS, Bermudez CC, Souza RA, Souza CMF, Dias EM, Castro CES, et al. Impacto da dor na vida de portadores de disfunção temporomandibular. J Appl Oral Sci 2003 jun.;11(2):138-43.

4. CALIXTRE LB, Grüninger BLS, Haik MN, Alburquerque-Sendín F, Oliveira AB. Effects of cervical mobilization and exercise on pain, movement and function in subjects with temporomandibular disorders: a single group pre-post test. J Appl Oral Sci 2016 jun.;24(3):188-97.

5. CALIXTRE LB, Grüninger BLS, Chaves TC, Oliveira AB. Is there an association between anxiety/depression and temporomandibular disorders in college students? J Appl Oral Sci 2014 Jan-Feb;22(1):15-21.

6. GIL-MARTINEZ A, Grande-Alonso M, Lopez-De-Uralde-Villanueva I, Lopez-Lopez A, Fernandez-Carnero J, La Touche R. Chronic Temporomandibular Disorders: disability, pain intensity and fear of movement. The journal of headache and pain 2016 Dec;17(1):103.

7. DE Godoy CH, Silva PF, De Araujo DS, Motta LJ, Biasotto-Gonzalez DA, Politti F, et al. Evaluation of effect of low-level laser therapy on adolescents with temporomandibular disorder: study protocol for a randomized controlled trial. Trials $2013 \mathrm{Jul}$ 22;14(229.

8. KRAUS S, Prodoehl J. Outcomes and patient satisfaction following individualized physical therapy treatment for patients diagnosed with temporomandibular disc displacement without reduction with limited opening: A cross-sectional study. Cranio : the journal of craniomandibular practice 2019 Jan;37(1):20-7.

9. KRAUS SL. Characteristics of 511 patients with temporomandibular disorders referred for physical therapy. Oral surgery, oral medicine, oral pathology and oral radiology 2014 Oct; 118(4):432-9.

10. KRAUS S, ProdoehI J. Disc displacement without reduction with limited opening: A clinical diagnostic accuracy study. Physiotherapy theory and practice 2017 Mar;33(3):23844.

RECEBIDO EM 02/04/2018

ACEITO EM 21/01/2019 